This item was submitted to Loughborough's Research Repository by the author.

Items in Figshare are protected by copyright, with all rights reserved, unless otherwise indicated.

\title{
United in opposition? The populist radical right's EU-pessimism in times of crisis
}

PLEASE CITE THE PUBLISHED VERSION

http://dx.doi.org/10.1080/07036337.2017.1281261

\section{PUBLISHER}

(C) Taylor \& Francis (Routledge)

\section{VERSION}

AM (Accepted Manuscript)

\section{PUBLISHER STATEMENT}

This work is made available according to the conditions of the Creative Commons Attribution-NonCommercialNoDerivatives 4.0 International (CC BY-NC-ND 4.0) licence. Full details of this licence are available at: https://creativecommons.org/licenses/by-nc-nd/4.0/

\section{LICENCE}

CC BY-NC-ND 4.0

\section{REPOSITORY RECORD}

Pirro, Andrea L.P., and Stijn Van Kessel. 2019. "United in Opposition? the Populist Radical Right's Eupessimism in Times of Crisis". figshare. https://hdl.handle.net/2134/23460. 


\title{
United in Opposition? The Populist Radical Right's EU-pessimism in Times of Crisis
}

Draft accepted for publication in Journal of European Integration on 23 November 2016

\author{
Andrea L. P. Pirro \\ Scuola Normale Superiore \\ andrea.pirro@sns.it
}

\author{
Stijn van Kessel \\ Loughborough University \\ s.van-kessel@lboro.ac.uk
}

\begin{abstract}
Populist radical right (PRR) parties are typically critical of European integration. They deem the EU an elitist project and consider European integration a threat to national sovereignty. Our article assesses whether, and how, PRR parties have changed their 'EU-pessimist' discourse following the outbreak of the Global Financial Crisis. The crisis has ostensibly provided scope for PRR parties across Europe to bolster their EU-pessimism and place more emphasis on socioeconomic frames. We analyse the evolution of the PRR's discourse in five countries. The article shows that, although PRR parties have generally brought the crisis into their discourses, they have responded to it in different ways, displaying varying degrees of EU-pessimism. These responses were partly informed by the opportunities provided by their contexts, but ostensibly more so by the strategic considerations of PRR party leaderships.
\end{abstract}

\section{Keywords}

Euroscepticism, Populism, Radical right, Political parties, Crisis 


\section{Introduction}

The rise of populist radical right (PRR) parties has been a salient theme among scholars and commentators alike. Before the refugee crisis took centre stage in the European public debates, the performance of successful PRR parties has been placed in the context of growing public dissatisfaction with the EU and worsening economic conditions following the financial crisis of 2008 (e.g. Brack and Startin 20I5). It has been assumed that, due to their growing hostility towards the EU, many voters resorted to PRR parties voicing antiEuropean messages (Economist 20I4).

As the ultimate bearers of national interests against supranational elites, PRR parties can indeed be identified as typical carriers of Eurosceptic views. Still, it has been observed that most PRR parties have lent diffuse support to European cooperation (Mudde 2007). In other words, irrespective of positional variations determined by their specific historical and political contexts, the overwhelming majority of PRR parties have neither presented themselves as entirely 'anti-European', nor advocated withdrawal from the EU (Vasilopoulou 20I I, 243-244).

Nonetheless, it can be expected that the escalation of public Euroscepticism provided an incentive for PRR parties to harden their opposition to 'Europe', and signal such stance to the electorate (Rohrschneider and Whitefield 20I5). As a reaction to the increased salience of the EU issue, furthermore, a critical attitude to 'Europe' may also have become more central to the appeal of PRR parties, instead of solely functioning as an ideological appendage' (Taggart 1998, 373). Finally, besides the intensity of their opposition to the EU, PRR parties may also have altered their substantive arguments against European integration. 
In the previous years, and certainly up until 20I5, public discontent with the EU has regularly been related to the socioeconomic consequences of the financial and Eurozone crises. In the specific timeframe running from 2008 (the year in which the Global Financial Crisis broke out) and 2015 (when public concerns on immigration overrode those on the economic situation; see European Commission 20I5). Traditionally inclined to cultural framings, PRR parties thus had an incentive to place more emphasis on economic issues in their EUpessimist discourse (see Helbing et al. 2010).

We then expect that, in a period of high salience of economic issues, PRR parties responded by linking their European discourse to economic arguments, and by placing more emphasis on them. While we attribute these hypothesised shifts to the changing European scenario after the breakout of the economic and financial crisis, we are aware that EU-pessimist frames may still have taken up different shades due to the different ways in which the crisis unfolded across countries.

Starting out from these premises, the aim of this article is to assess whether, and how, PRR parties have changed their EU-pessimist discourse following the outbreak of the Global Financial Crisis. Did PRR parties recognise an opportunity to intensify their opposition to Europe? Did they frame opposition to European integration using different issues and arguments compared with the past? We additionally seek to decipher possible changes and cross-national variety in the PRR's EU-pessimist discourse, and consider whether a particular set of contextual opportunities can throw light on changes in party-based EU-pessimism, or whether such changes can be interpreted as strategic decisions by the party leadership. The study analyses the discourse of PRR parties in five countries (Belgium, Hungary, Italy, the Netherlands, and Slovakia), and explores whether possible changes in the nature of their EU- 
pessimism can be related to increased public opposition to EU membership, attributed to party competition dynamics and incumbency status, or rather be linked to changes in party leadership.

The following section discusses our theoretical starting points. The subsequent section analyses the evolution of the EU-related discourse of five PRR parties. The final section summarises the findings and concludes that, although PRR parties have generally brought the crisis into their discourses, the events did not have a uniform impact on the discourse of PRR parties, nor the intensity of their EU-pessimism. Variations in patterns of EU-pessimism may be reconciled with the strategies of their (new) leaders, ostensibly more so than the distinct opportunities provided by their contexts. Hence, despite observing certain similarities, it is still important to qualify the notion that the PRR is united in its opposition to Europe.

\section{A PRR's Radicalisation vis-à-vis the EU?}

The PRR party family is believed to share a common core of nativism, authoritarianism, and populism (Mudde 2007). Most of these parties are naturally sceptical of the process of European integration (Hooghe et al. 2002; De Vries and Edwards 2009); the PRR typically portrays the EU as a project that threatens the sovereignty of the native people and, through the opening of borders, the cultural homogeneity of nations. Furthermore, the complex and elite-driven European decision-making process is at odds with the populist anti-establishment appeal of these parties (e.g. Mudde 2007). 
In general, PRR parties can be regarded as 'EU-pessimists', as they “do not support the EU as it is at the moment, or are pessimistic about the direction of its development" (Kopecký and Mudde 2002, 302). The EU-pessimist category serves as a container for 'Eurosceptic' and 'Euroreject' parties. Whereas 'Eurosceptics support the general ideas of European integration, but are pessimistic about the EU's current and/or future reflection of these ideas", Eurorejects "subscribe neither to the ideas underlying the process of European integration nor to the EU” (Kopecký and Mudde 2002, 302).' Mudde (2007, 164) has observed that most PRR parties have been 'Eurosceptic', rather than 'Euroreject', since they did not generally reject outright the idea of political and economic integration.

We however expect that the financial and economic crises offered scope for PRR parties to increase their opposition against 'Europe'. The central role of 'crisis' for populist mobilisation has been extensively discussed (e.g. Taggart 2000; Moffitt 20I5), suggesting that the crisis is a construct moulded by populist actors in order to pit 'the good people' against 'the bad elite'. In financially troubled EU countries, the crisis has seemingly provided populist parties with a concrete opportunity to voice their dissent with the stipulations of the European Commission, as well as member states (above all, Germany) that insisted on austerity measures. Thus, the PRR had the opportunity to tap into the discontent of citizens who blamed the EU for its presumed mismanagement of the crisis (Gomez 20I5).

However, the scope for PRR parties to emphasise their opposition to Europe was not necessarily related to the gravity of the economic and financial downturn in respective countries (Braun and Tausendpfund 20I4). In less hard-hit countries, PRR parties, as the ultimate defenders of national interest, were inclined to express opposition to the bailing out of financially troubled EU members and the transfer of sovereignty to the European level in 
response to the crisis. Thus, although 'the crisis' has been experienced and construed in various ways across Europe, it has ostensibly provided PRR parties throughout the EU with new ammunition against the process of European integration.

While Euroscepticism has been convincingly defined as an ideological appendage of peripheral parties of both the left and right (Taggart 1998; Hooghe et al. 2002), the PRR has become the dominant EU-pessimist party family (Gómez-Reino and Llamazares 2013). The crisis, primarily socioeconomic in character, seemingly offered the PRR incentives to extend its EU-pessimist discourse beyond questions of national sovereignty and to focus more explicitly on economy-related issues - once prerogative and drive of radical left-wing Euroscepticism (cf. De Vries and Edwards 2009). Thus, with the crisis boosting the salience of economic issues, PRR parties would be expected to devote more attention to economic frames, in addition to the traditionally prevailing cultural ones (Helbling et al. 2010).

In our analysis, we examine more closely the recent EU-related discourse of PRR parties in various parts of Europe, and assess to what extent PRR parties are truly 'united in opposition'. We focus on the (different) ways in which PRR parties have framed the issue of European integration in recent years, and explore possible interpretations concerning the nature and intensity of their opposition.

Interpreting Variation in the EU-pessimist Discourse of the PRR 
As far as the nature and intensity of the PRR's opposition to 'Europe' are concerned, we expect that contextual elements as well as internal supply-side factors affect the EUpessimist stance of these parties.

Previous studies have pointed out that parties on the fringes of the political spectrum can attract voters on the basis of their Eurosceptic platform (De Vries 2007, 2010; Werts et al. 20I3). Against a backdrop of mounting public Euroscepticism during the crisis (Serricchio et al. 20I3; Gomez 20I5), PRR parties would then have good reasons to sharpen their opposition to 'Europe' and attempt to consolidate their ownership of the issue. Especially in countries where public calls to end EU membership have become louder, we would expect PRR parties to have shifted towards all-out Eurorejection.

This notwithstanding, other political parties, including mainstream competitors, may also be prone to adapt to souring public attitudes; indeed, Euroscepticism is no longer an exclusive prerogative of fringe parties (Taggart and Szczerbiak 2013). We must therefore take into account the changing stances of other parties vis-à-vis the EU and the effects that these dynamics may have on the PRR's discourse. Particularly those mainstream parties that have previously demonstrated willing to co-opt part of the PRR's agenda would be expected to respond to the PRR's radicalisation (Meijers 20I5). In turn, we anticipate that the PRR would radicalise its EU-pessimist discourse, and thus adopt Euroreject positions, in the presence of a mainstream competitor with a Eurosceptic stance, as a means to further differentiate itself from mainstream parties (Taggart 1998).

In addition, the incumbency status of PRR parties is likely to matter. Several members of this party family have taken government responsibility over the course of the past decades. As 
far as party system dynamics are concerned, previous studies demonstrated that incumbency tends to temper party-based Euroscepticism (Arnold et al. 2012; Taggart and Szczerbiak 2013); in other words, parties enjoying government responsibilities are likely to adapt to the 'pro-EU consensus' prevailing among national elites. We would then expect members of the PRR party family to mitigate their opposition to Europe in government, and to witness radicalisation only among PRR parties in opposition.

Finally, we assume that party-based ideological changes may also depend upon internal organisational and strategic elements, instead of external stimuli alone. Parties' own agency has rarely been factored into the equation of positional change. In particular, one factor that may contribute to altering the programmatic trajectory of a party is leadership change, whether incidental or part of a broader commitment to ideological rejuvenation (Harmel and Janda 1994). Especially among PRR parties, which are often characterised by a hierarchical organisational structure, a leadership change may result in a considerable transformation of the party's outlook in a number of policy fields.

\section{Methodology and Case Selection}

A qualitative line of enquiry suits the explorative purposes of this study. As we not only aim at mapping and interpreting shifting party positions, but also at exposing substantive arguments and the way these developed over time, we conduct an in-depth analysis of PRR parties' discourse in five countries. Besides initial reference to expert survey data, our study relies on qualitative content analyses of party manifestos, in that these strategic documents are widely recognised as the most reliable source of ideological stances and allow us to 
retrieve data on party policies across time (Laver and Garry, 2000). Since our focus is on the PRR's discourse after the outbreak of the Global Financial Crisis in 2008, we monitor party discourses from the mid-2000s onwards.

As far as case selection is concerned, we look at developments in Belgium, Hungary, Italy, the Netherlands, and Slovakia; thereby, we strike a balance between old and new EU member states. The contextual variety allows us to address the question of whether or not PRR parties throughout Europe have remained broadly similar in terms of the intensity of their EU-pessimism and their framing of European integration. While the parties included in this study have diverse agendas, they do share a common denominator of nativism, authoritarianism, and populism (Mudde 2007; Pirro 2015). Furthermore, this study focuses specifically on the PRR's position on European integration - an issue on which different PRR parties traditionally formulated similar arguments (e.g. De Vries and Edwards 2009).

In selecting our cases, we sought variation in the levels of public Euroscepticism, party competition, incumbency status, and changes in party leadership (Table I) - that is, those elements that should help decipher possible variation in the EU-pessimist discourse of PRR parties. Although we should be cautious in drawing general conclusions from this small-N research design, contextual variations allow us to explore whether a particular set of conditions may have contributed to PRR parties' radicalisation on Europe (or lack thereof) in selected countries.

$<$ TABLE I HERE $>$ 
Variation can, first of all, be observed in the levels of support for EU membership (European Commission 20I4a; 20I4b, 85). ${ }^{2}$ In Italy, traditionally a Europhile country, positive attitudes on EU membership reached an all-time low during the crisis. If asked about their views on Europe, the Hungarian public showed mounting opposition to the EU already before the outbreak of the crisis, but more recent figures place the country close to the EU28 average. A clear majority of Slovaks, on the other hand, considered EU membership to be a good thing up until 2010 , but afterwards public attitudes soured and went to resemble the EU28 average. In the Netherlands, support for a Dutch withdrawal from the EU has remained very limited, and lowest across all member states. Belgium's population, finally, has remained similarly committed to EU membership, with two-thirds of the Belgians considering EU membership to be a good thing between 2008 and $201 \mathrm{I}$.

\section{<FIGURE I HERE>}

The five countries also differed in terms of the competition that PRR parties had to endure from mainstream rivals over the EU issue. Figure I provides visual complement to this, presenting data from the Chapel Hill Expert Survey (CHES) on the overall orientation of party leaderships towards European integration (Bakker et al. 20I5). Besides cross-national and cross-temporal variation in the positions of PRR parties, those of the mainstream competitors also show notable variation. As will be discussed in more detail in the next section, Fidesz - Magyar Polgári Szövetség (Hungarian Civic Alliance, Fidesz) in Hungary embarked on a Eurosceptic course during the second Orbán government (2010-14). The Dutch centre-right Volkspartij voor Vrijheid en Democratie (People's Party for Freedom and Democracy, VVD) never dropped its commitment to EU membership, but became more sceptical of further political integration in recent years. In Italy, Silvio Berlusconi's parties, 
traditionally EU-optimist, embarked on a more Eurosceptic course only late into the crisis (McDonnell 20I4). In Belgium and Slovakia, on the other hand, the mainstream competitors of the PRR essentially maintained EU-optimist positions.

This study further includes two countries in which PRR parties remained in opposition during the years of the crisis (Belgium and Hungary), two in which PRR parties took government responsibility (Italy and Slovakia), and one in which a PRR party provided parliamentary support for a governing minority coalition (the Netherlands). By means of these latter three cases, we can judge whether government participation or support constrained PRR parties in their opposition to Europe, and whether these parties intensified their opposition after they left office.

Concerning the final condition outlined, we pit three PRR parties (in Belgium, Italy, and Slovakia) that have undergone leadership changes during the period analysed against two that have maintained the same leader throughout (Hungary and the Netherlands). This should indicate whether patterns of change and continuity vis-à-vis 'Europe' could be reconciled with party leadership changes.

\section{Europe and the PRR in Five Countries}

\section{Belgium}

The only electorally relevant PRR party in Belgium, Vlaams Belang (Flemish Interest, VB) until 2004 named Flemish Block - was the only party in Belgium to consistently vote against 
all EU treaties since Maastricht. Neverheless, the VB's criticism of 'Europe' can be considered milder compared with other European PRR parties (Deschouwer and Van Assche 2008). The party has traditionally focused more on the 'regional' issue in Belgium, campaigning for Flemish independence and directing its criticism mainly to the (Francophone) elites at the federal level.

In fact, the ultimate goal of the VB was for Flanders to become an independent member state of the EU, and the party supported cooperation between 'European Peoples', as long as this did not result in the creation of a 'super state', threatening the sovereignty of individual cultural communities (Swyngedouw et al. 2007; VB 2007, 5). As far as arguments against the EU are concerned, the VB denounced the EU's democratic deficit, oversized bureaucracy and spendthrift in its elaborate 2009 EP election manifesto (VB 2009). At the same time, however, the VB favoured more effective European cooperation in areas such as defence and foreign affairs - not in the last place to stop immigrants from entering 'Fortress Europe' and counter 'Islamisation'.

In the manifesto for the 2014 federal, regional, and EP elections - all held on the same day the VB desired an "orderly dismantling of the EU and of the Eurozone", to replace it with a more non-committal intergovernmental form of cooperation, and a smaller monetary union (VB 20I4, 9). The party also opposed the European Stability Mechanism and the transfer of money from north to south European Eurozone members - which the VB likened to the financial transfers from Flanders to Wallonia. As such, the VB clearly reacted to developments related to the Eurocrisis and expanded its Eurosceptic repertoire, though without calling for a Belgian withdrawal from the EU. 
The VB had ostensibly little reason to shift towards all-out Eurorejection in view of the relatively low levels of public Euroscepticism and the limited salience of the issue. Of the mainstream parties, only the Flemish-nationalist Nieuw-Vlaamse Alliantie (New-Flemish Alliance, N-VA) - which increasingly posed an electoral threat to the $\mathrm{VB}^{3}$ - became more critical of European integration in the 2014 campaign (Leruth 2014). This did not mean, however, that Euroscepticism had become a core value of the party, and the party's orientation towards European integration still leaned towards the positive side (Figure I).

In the end, the VB maintained its position as the most Eurosceptic party in Belgium. In terms of its framing of 'Europe', the VB reacted to the events of the financial and Eurozone crises, placing more emphasis on the financial and economic problems caused by European integration. In terms of its position on European integration, the VB's stance was primarily characterised by continuity, and the party did not shift towards Eurorejection. The various leadership changes during the period of investigation did little to alter the party's overall position on the issue.

Hungary

Similar to other PRR parties, the stance of the Jobbik Magyarországért Mozgalom (Movement for a Better Hungary, Jobbik) on Europe has been erratic, yet driven by pessimism throughout. In its first electoral manifesto of 2006, the party associated EU membership with a treacherous loss of national sovereignty. Jobbik's position was grounded in the perception that the Hungarian accession was agreed on unfair and unfavourable terms, with the consequence of endangering vital national assets (Jobbik 2006). The party appealed to 
withdrawal from the EU by means of a referendum, depicting the EU as one of the multiple harmful facets of globalisation.

Despite the breakout of the economic crisis, Jobbik toned down its Euroreject rhetoric and even appraised the EU as a platform for the resolution of questions of national interest, such as national minorities living abroad (Jobbik 2010,55). Starting from the year 2012, however, the party articulated fierce anti-EU rhetoric and placed greater emphasis on the issue. Using an interrelated series of political and economic circumstances as a catalyst for dissent (e.g. EU criticism on the new Hungarian constitution and Hungary's economic dependence on the IMF, EU, and World Bank), Jobbik held a number of anti-EU demonstrations, and appealed to Hungary's exit from the Union (Jobbik 20I2).

Jobbik continued on this track throughout the year 2014. Still, the crisis-related and anti-EU discourses remained distinct in the 2014 manifesto. While the party maintained a negative outlook on the EU (referring to questions related to Hungarian sovereignty and interests), Jobbik attributed responsibility of the crisis to neoliberal globalism and the nefarious policies of the previous governments (Jobbik 20I4, 33-34). Hence, the party's opposition to the EU stemmed from a broader negative assessment of Hungarian membership, and was not a direct reaction to the (mismanagement of the) economic crisis.

To interpret Jobbik's EU-pessimist course, two contextual factors must be taken into account. First, Europe never figured prominently in the Hungarian debate - notwithstanding Hungary's considerable levels of public Euroscepticism. Second, by the time the economic crisis hit the country in late 2008 , Hungary had already been struck by an internal political crisis of substantial magnitude. ${ }^{4}$ In 2008, moreover, the Socialist-led government was 
compelled to request a $\$ 25$ billion bailout package from the IMF, EU, and World Bank to face the crisis; when the austerity measures were implemented, then, it was the government, rather than the EU, that came across as a specific target for criticism.

As far as party competition over 'Europe' is concerned, a marked change in party-based EUpessimism has materialised since Fidesz's coming to power in 2010. Fidesz, Jobbik's mainstream competitor, essentially revived its dormant Euroscepticism (Gulyas 2013). As Fidesz launched an extensive process of reform, party leader and PM Orbán became object of severe criticism by the European Commission; in turn, Orbán repeatedly delegitimised the 'undemocratic' European architecture, thereby largely adopting the PRR's EU-pessimist discourse (Bíró Nagy et al. 2013). As a means to set the governing and ever-radicalising Fidesz at a distance, Jobbik maintained that Orbán spoke 'with two tongues', arguing that, while he had claimed to defend Hungarian interest at the EU level, no deeds had actually followed (Jobbik 20I4, 80-8I).

The EU issue substantially served as a novel dimension of contestation between Jobbik and the party of PM Orbán. Fidesz shifted from the EU-optimist position of the 2000s to an EUpessimist stance reminiscent of Jobbik (Pirro 2015) - a strategy part of Orbán's general bid to co-opt parts of Jobbik's agenda in an attempt to win the more radical right-wing electorate (see Bíró Nagy et al. 2013). Jobbik's appeals to exit the EU can be interpreted as a 'race to the extremes' - a means to differentiate from Fidesz's growing EU-pessimism and increasing radicalisation.

Italy 
The Lega Nord (Northern League, LN), originally an EU-optimist organisation, had already relocated to Eurosceptic territories by the late 1990s (Huysseune 2010). Over the years, however, the LN's critical outlook on Europe has been defined and mitigated by the alliance with Berlusconi's Casa delle Libertà (House of Freedoms, CdL; later, People of Freedom, PdL). As a case in point, in the joint $2006 \mathrm{CdL}$ electoral manifesto, the coalition (comprising the $\mathrm{LN}$ ) reaffirmed its commitment to Europe, hereby including budget constraints and EU laws (CdL 2006, 9).

By the time the crisis broke out, the LN had returned to government as part of the centreright coalition, and released a programmatic document that opposed the current model of integration: the EU was defined as an "undemocratic super-state" acting against the interests of European peoples and their traditions (LN 2009, 60). The LN reasserted its vision of a "Europe of the regions and territories" - a Europe of the peoples, ultimately able to preserve their sovereignty and fulfil the regionalist aspirations of the party (LN 2009, 6I). Besides confirming the cultural framing of its Eurosceptic stance and reiterating the importance of the Christian roots of Europe and its opposition to Turkish entry to the EU, the LN did not call for exits from the EU or the Eurozone. Moreover, neither the EU nor its policies were deemed directly responsible for the economic situation of the country.

The LN contested the 2013 national election on the basis of a programme aiming at overcoming the austerity imposed by EU policies, yet through the acceleration of the 'four unions' - i.e. political, economic, banking, and fiscal (LN 20I3, 3). The turning point for the LN's strategic and ideological course came with the election of Matteo Salvini to federal secretary in December 2013. The LN, already in opposition, but now also freed from 
political alliances with the PdL, revealed the full scope of its EU-pessimism during the 2014 European elections campaign. Although the LN did not explicitly call for withdrawal from the $\mathrm{EU}$, the party referred to exit from the Euro as a measure impossible to postpone, thus relating the crisis to the introduction of the Euro - described as "a criminal error" (LN 2014 , I5). Elaborating on the economic framing of its oppositional stance, the LN explicitly linked the EU to the power of banks and finance, and set itself in opposition to Brussels, which supposedly aimed to interfere in single member-states' fiscal and monetary policies (LN 2014, 17).

The radicalisation of the LN's discourse can be read through the domestic political context. Previously, within the context of widespread party-based loyalty towards the EU (Roux and Verzichelli 2010) and an EU-optimist population, Europe could not be considered a mobilising theme. More recently, both public disenchantment with EU institutions and the economic situation offered prospects for Eurosceptic frames elaborated along cultural and economic lines, and the LN seemed to have capitalised on this opportunity. ${ }^{5}$

To understand why the LN only intensified its opposition to the EU relatively late into the crisis, the LN's limited room for manoeuvre as coalition partner needs to be taken into account. While in government, and also for a limited time in opposition between $20 \mathrm{II}$ and 20I3, the LN had to compromise on EU-related issues (Conti and De Giorgi 20II) - often exhibiting inconsistencies between deeds and words (Albertazzi and McDonnell 2010). Once in opposition and freed from political alliances with moderate coalition partners, the party could fully articulate its Eurosceptic stand. Remarkably, however, Berlusconi's Forza Italia was later also seen to respond to the high levels of public Euroscepticism by using Eurosceptic messages (McDonnell 20I4). 


\section{The Netherlands}

The Partij voor de Vrijheid (Party for Freedom, PVV) made its stance on the EU clear in its first party document, written before its entrance into the Dutch parliament in 2006. Party leader Geert Wilders voiced opposition against Turkish EU accession, lamented the loss of sovereignty and the erosion of Dutch identity as a result of European integration, and criticised the EU's undemocratic character (Wilders 2005). Amid soaring popularity, Wilders' party upheld its Eurosceptic course.

The PVV focused more than ever on 'Europe' in the parliamentary election campaign of 2012, which followed the party's withdrawal of parliamentary support from the governing minority coalition. Notably, the manifesto was titled 'Their Brussels, Our Netherlands', with the PVV speaking derogatively of "unelected multi-culti Eurocrats", and the "holy GreatEuropean project" (PVV 20I2, II-12). Meanwhile, national-level politicians were blamed for their submissive compliance with the "dictates from Brussels", surrendering national sovereignty to 'Europe', and wasting taxpayers' money on supporting corrupt countries such as Greece and Romania in a time of domestic economic hardship.

In the run-up to the 2014 EP election, the PVV (20I4) continued to voice its commitment to leave the EU, abandon the Euro, and close the Dutch borders for Eastern European labour migrants (besides people from Islamic countries). Wilders' party furthermore demanded back the money lent to "bankrupt countries and banks". The PVV thus responded to the Eurozone crisis by focusing more than before on the negative financial and socioeconomic 
consequences of European integration. What is more, Wilders' party also radicalised its position towards European integration; since 2012, the PVV has favoured an unconditional Dutch withdrawal from the EU and the Eurozone.

When the domestic political context is taken into account, it is interesting to note that Wilders embarked on his vigorous Euroreject course despite the fact that popular support for a Dutch 'exit' remained limited. This suggests that the PVV leader may have sought to fuel, rather than merely tap into, Euroreject sentiments. ${ }^{6}$ The PVV was also the only major party in the Netherlands that truly aimed to politicise the issue of European integration, and no other party would follow the PVV in its opposition to EU membership (Van Kessel and Hollander 2012). The PVV's mainstream competitors, most notably the liberal VVD, were careful not to come across as Europhile. In recent years, the VVD took a sceptical and pragmatic approach to European cooperation, but nevertheless recognised the benefits of EU membership (VVD 20I4). The most EU-pessimist party besides the PVV was the radical left-wing Socialistische Partij (Socialist Party, SP), which did not call for a Dutch exit and was, furthermore, not the closest electoral rival of the PVV (Van der Meer et al. 2010). All in all, the PVV's push towards Eurorejection can be interpreted as an autonomous move, rather than a reaction to competitors' pressure.

Finally, the PVV's role as support partner for a centre-right minority coalition (2010-12) did not have a clear effect on Wilders' Euroscepticism. Although the PVV was ostensibly constrained in its criticism of the government, Wilders could continue to voice dissatisfaction with the cabinet's actions in the areas of immigration and European integration, which were not covered by the support agreement. It is clear, however, that the 
PVV radicalised its opposition and embarked on a Euroreject course immediately after withdrawing support from the coalition.

\section{Slovakia}

The main EU-pessimist force in Slovakia has been the Slovenská Národná Strana (Slovak National Party, SNS). After its re-emergence as a unitary party in the mid-2000s, the SNS showed evident signs of pragmatism in its position on 'Europe'. The party has systematically opposed the project of a 'United States of Europe', and iterated the EU's responsibility for respecting and protecting the sovereignty of its member states - though also aspiring to take advantage of EU structural funds (SNS 2006, 3). The party maintained an analogous Eurosceptic outlook in the run-up to subsequent elections.

Despite denouncing a progressive loss of national sovereignty in a number of policy fields due to the process of European integration, the 2010 programme served primarily as an account for the SNS' achievements as a junior coalition partner during the 2006-10 term. The party did include pragmatic considerations, taking credit for the allocation of over 99 per cent of the EU structural funds and the adoption of the Euro (SNS 2010). In other words, the party combined negative cultural and rather positive economic frames of Europe.

The political and financial scenario had changed by the time of the early 2012 election. The fall of the government coalition led by Iveta Radičová was triggered by a vote of no confidence over support for the European Financial Stability Fund (Malová and Učeň 20I2). Accordingly, the Eurozone crisis had taken centre stage in the 2012 memorandum of the 
SNS. For the first time since EU accession, the party explicitly appealed to withdrawal from the EU and the end of the common currency (SNS 2012, I). The party document was permeated with calls for Slovak sovereignty, self-sufficiency, and patriotism, but this time placed in the context of the EU's financial and structural failure. The SNS rejected the principles of EU solidarity as they were seen to sustain a monetary system based on debt and loss (SNS 20I2, 2). Moreover, the EU leadership was portrayed as an unaccountable elite, which served the interests of multinational financial groups, monopolies, and globalists (SNS 2012, I0). Hence, the party also included negative economic frames within its Euroreject outlook.

Having failed to win any seats in the 2012 election, the SNS underwent a leadership change aimed at rebuilding the image of the party. The party's motto for the 2014 European elections was 'be partners, not slaves!', and the SNS once again put itself in defence of Slovak sovereignty and Slovak citizens against supranational and financial elites. On this occasion, the EU was depicted as a "bureaucratic Moloch" seeking to further deprive nation states of their decisional capacity (SNS 2014). Although the SNS has firmly incorporated cultural and economic frames in its Eurosceptic discourse, it did not explicitly call for a withdrawal from the EU or the Eurozone and, thus, shied away from an all-out Euroreject discourse - a strategy that appears in line with the new leadership's attempt to deliver a more moderate self-image (Pirro 20I5).

Looking at the broader context, the SNS initially adapted to the relatively pro-European attitudes of the Slovak public that revealed upon EU accession, abandoning the Euroreject positions of the 1990s (Pirro 2014). Amid recent electoral failures, however, the party briefly took a Euroreject trajectory. The motives of this radicalisation have been 
circumstantial and very much related to the Eurozone crisis. Having acknowledged the limited electoral benefits deriving from outright rejection of the EU, the new leadership steered the party back to Eurosceptic territories. At the same time, as other mainstream parties have upheld a fairly EU-optimist outlook (e.g. Malová and Učeň 20I3), the SNS's recent EU-pessimist swings cannot be considered part of a broader competition over the issue, but should be read through the lens of the different political strategies pursued as well as opportunities identified by its leaders.

\section{Conclusions}

The PRR has often been interpreted as a monolithic 'anti-EU' bloc, and singled out as a political force that could benefit from the breakout of the Great Recession (see Economist 20I4). Starting out from the premise that the recent economic and political turbulence has offered incentives for PRR parties to bolster their opposition to the EU, this article set out to explore whether, and how, PRR parties developed their EU-pessimist discourse following the outbreak of the Global Financial Crisis. While the crisis had no analogous implications across the EU, it certainly provided a common context of reference for EU-pessimist forces. Our study presented a rather composite picture.

For one, our analysis of the PRR in the five countries showed that these parties did not coalesce in an all-out rejection of European integration and EU membership. The stances of the PRR are more diverse than is often assumed and 'the crisis', however construed, has not fundamentally changed this. This is not to say that the recent political and economic developments left the discourses of PRR parties unaffected. To different degrees, all reacted 
negatively to austerity measures and/or the transfer of further sovereignty to the European level, at times ending up prioritising economic frames in their EU-pessimist ideology (cf. Helbling et al. 2010).

Nonetheless, the crisis has played out in different ways across contexts. In Hungary, for instance, Jobbik's calls for exit from the EU were not strictly related to the austerity measures imposed by the EU. What is more, not all parties moved consistently towards a fiercer EU-pessimist stance during the crisis: the positions of the Hungarian Jobbik, Italian LN, and the Slovak National Party wavered during the period of study, whereas the course of the Belgian VB was essentially marked by consistency (cf. Rohrschneider and Whitefield 20I5).

The contextual conditions identified in this article only partly help us decipher differences across countries and time. First, regarding levels of public Euroscepticism, Jobbik in Hungary, the LN in Italy, and the SNS in Slovakia were found to radicalise amid mounting or substantial public opposition to EU membership. However, the SNS actually moderated its EU-pessimist profile in later years, despite the fact that public approval for EU membership remained at record lows. Considering the general pro-membership consensus in the Netherlands, furthermore, it is surprising at first sight that the PVV evolved into a Euroreject party.

Second, PRR parties' radicalisation does not necessarily stem from competition with mainstream rivals over the issue. PRR parties in Italy, the Netherlands, and Slovakia were found radicalising in the absence of, or prior to, a mainstream competitor challenging their EU-pessimism. In Hungary, on the other hand, domestic party competition did play a crucial 
role in Jobbik's Euroreject appeal.

Third, based on our analysis and in line with previous research, the PRR's status in opposition seemingly offers scope for radicalisation on the EU (Arnold et al. 2012; Taggart and Szczerbiak 20/3). While opposition parties did not have any incentive to moderate their EU-related discourse in times of crisis, those who were once coalition partners (the LN and SNS), or provided support to minority governing coalitions (the PVV), adopted a more radical stance after they left government.

Contextual conditions aside, it is ultimately up to the parties' leaderships to act upon the given opportunities. Indeed, in two cases (LN and SNS) changes in the EU-pessimist discourses were triggered more by leadership changes than developments in the wider political and economic context. More generally, it is difficult to predict PRR parties' courses on 'Europe' by purely considering the context in which they operate, as their positions cannot be understood unless the (often contingent) strategic considerations of the party leadership are taken into account. Even in countries where the demand for leaving the EU is minimal, PRR parties may try to create their own opportunities by attempting to fuel Euroreject sentiments among the electorate - the Dutch PVV being a case in point.

The study helps to reinstate the role of agency in the ideological trajectory of PRR parties. PRR parties behave differently across countries, even when facing similar economic conditions, levels of public Euroscepticism, or strategies of mainstream competitors. This implies that they are not necessarily reactive forces that pander to public opinion or adjust to their party-political context in an entirely predictive manner. While some have aimed to set the agenda by radicalising and actively politicising European integration - albeit only 
temporarily -, others have attached less value to the issue and remained Eurosceptic rather than Euroreject. Although PRR parties may be broadly similar in their EU-pessimism, we should thus be aware of its various shades across time and space. It is not only context, but also the strategic decisions of the party leadership, that condition how fiercely opposed a PRR party is to 'Europe'.

Further research should clarify whether the crisis in Europe also had consequences for the electoral fortunes of PRR parties, and whether EU-pessimism, in its most radical shades, could be considered a viable strategy for this party family. In view of more recent developments, and the refugee crisis in particular, it will be crucial to ascertain whether an increased emphasis on economic frames could be a lasting feature of the PRR's EU-pessimist discourse. PRR parties can be then expected to return to their trademark cultural framing of 'Europe' once related questions provide favourable discursive opportunities in domestic political debates.

\footnotetext{
'A similar notion of maximal opposition to the EU is recognisable in other conceptual frameworks, which refer to 'hard', as opposed to 'soft', Euroscepticism (Taggart and Szczerbiak 2008, 7-8), or a 'rejecting', as opposed to a 'compromising' or 'conditional', pattern of Euroscepticism (Vasilopoulou 20II).

${ }^{2}$ After May 20II, the Eurobarometer ceased to include the question: 'Generally speaking, do you think that (your country's) membership of the European Community (Common Market) is a good/bad thing?'. To gauge more recent opinions on EU membership, we used the item asking respondents whether they agreed or disagreed with the statement that their country could better face the future outside the EU.

${ }^{3}$ Seeing many voters switching to the N-VA, the VB experienced electoral decline and received 3.7 per cent of the national vote in the 2014 federal election; a far cry from the 15.4 per cent gained in 2003.

${ }^{4}$ A political scandal broke out in 2006 following the disclosure of a private speech given by PM Ferenc Gyurcsány (Hungarian Socialist Party, MSZP), in which he admitted to have lied on the state of the Hungarian economy in order to win the April elections.

${ }^{5}$ Besides the LN, also Beppe Grillo's new Movimento 5 Stelle (5 Star Movement, M5S) voiced a Eurosceptic rhetoric.
} 
${ }^{6} \mathrm{It}$ is questionable whether the PVV's Euroreject course was electorally rewarding (see Van Kessel 2015). Both the 2012 national as well as the 2014 EP election marked losses for the PVV, which received 10.I and I3.2 per cent of the vote in these elections, respectively. 


\section{References}

Albertazzi, D., and D. McDonnell. 2010. The Lega Nord Back in Government. West European Politics 33, no. 6: $1318-40$.

Arnold C., E. Sapir, and C. De Vries. 2012. Parties' Positions on European Integration: Issue Congruence, Ideology or Context?. West European Politics 35, no. 6: I34I-62.

Bakker, R., et al. 2015. 1999-2014 Chapel Hill Expert Survey Trend File. Chapel Hill, NC: University of North Carolina, Chapel Hill.

Bíró Nagy, A., T. Boros, and Z. Vasali. 2013. More Radical than the Radicals: The Jobbik Party in International Comparison. In Right-Wing Extremism in Europe. Country Analyses, Counter-Strategies and Labor-Market Oriented Exit Strategies, ed. R. Melzer and S. Serafin, 229-53. Berlin: Friedrich-Ebert-Stiftung.

Brack, N., and N. Startin. 2015. Introduction: Euroscepticism, from the Margins to the Mainstream. International Political Science Review 36, no. 3: 239-49.

Braun, D., and M. Tausendpfund. 2014. The Impact of the Euro Crisis on Citizens' Support for the European Union. Journal of European Integration 36, no. 3: 231-45.

CdL. 2006. Programma Elettorale 2006. Election manifesto.

Conti, N., and E. De Giorgi. 20II. L'Euroscetticismo a Parole: Lega Nord e Rifondazione Comunista, tra Retorica e Comportamento Istituzionale. Rivista Italiana di Scienza Politica 4I, no.2: 265-89.

Deschouwer, K., and M. Van Assche. 2008. Hard but Hardly Relevant: Party-based Euroscepticism in Belgium. In Opposing Europe? The Comparative Party Politics of Euroscepticism. Volume I: Case Studies and Country Surveys, ed. A. Szczerbiak and P. Taggart, 75-92. Oxford: Oxford University Press.

De Vries, C. 2007. Sleeping Giant: Fact or Fairytale? How European Integration Affects 
National Elections. European Union Politics 8, no. 3: 363-85.

De Vries, C. 2010. EU Issue Voting: Asset or Liability? How European Integration Affects Parties' Electoral Fortunes. European Union Politics II, no. I: 89-II7.

De Vries, C., and E. Edwards. 2009. Taking Europe to Its Extremes: Extremist Parties and Public Euroscepticism. Party Politics I5, no. I: 5-28.

$\begin{array}{llllll}\text { Economist. } & \text { 20I4. } & \text { Turning } & \text { Right. } & 4 & \text { January. }\end{array}$ http://www.economist.com/news/briefing/21592666-parties-nationalist-right-arechanging-terms-european-political-debate-does (accessed 30 December 20I5).

European Commission. 2014a. Eurobarometer Interactive Search System. http://ec.europa.eu/public_opinion/cf/index_en.cfm (accessed 30 December 20I5).

European Commission. 20l4b. Public Opinion in the European Union. Standard Eurobarometer 8I, Spring 2014.

European Commission. 20I5. Public Opinion in the European Union. Standard Eurobarometer 83, Spring 2015.

Gomez, R. 2015. The Economy Strikes Back: Support for the EU during the Great Recession. Journal of Common Market Studies 53, no. 3: 577-92.

Gómez-Reino, M., and I. Llamazares. 2013. The Populist Radical Right and European Integration: A Comparative Analysis of Party-Voter Links. West European Politics 36, no. 4: 789-8I6.

Gulyas, V. 2013. Hungary Isn't Euro-Sceptic But “Euro-Realistic,” Premier Says. Wall Street Journal, 17 September. http://blogs.wsj.com/emergingeurope/2013/09/17/hungary-isnteuro-sceptic-but-euro-realistic-premier-says (accessed 30 December 20I5).

Harmel, R., and K. Janda. 1994. An Integrated Theory of Party Goals and Party Change. Journal of Theoretical Politics 6, no. 3: 259-287.

Helbling, M., D. Hoeglinger, and B. Wuest. 2010. How Political Parties Frame European 
Integration. European Journal of Political Research 49, no. 4: 495-52I.

Hooghe, L., G. Marks, and C. Wilson. 2002. Does Left/Right Structure Party Positions on European Integration?. Comparative Political Studies 35, no. 8: 965-89.

Huysseune, M. 2010. A Eurosceptic Vision in a Europhile Country: The Lega Nord. Modern Italy I5, no. I: 63-75.

Jobbik. 2006. A Jobbik 2006-os Rövid Programja. Election manifesto.

Jobbik. 2010. Radikális Változás. A Jobbik Országgyülési Választási Programja a Nemzeti Önrendelkezésért és a Társadalmi Igazságosságért. Election manifesto.

Jobbik. 2012. Jobbik Leaders Urge Hungary to Quit EU. http://www.jobbik.com/jobbik_leaders_urge_hungary_quit_eu (accessed 30 December 20I5).

Jobbik. 20I4. Kimondjuk. Megoldjuk. Választási Program 2014. Election manifesto.

Kopecký, P., and C. Mudde. 2002. The Two Sides of Euroscepticism. Party Positions on European Integration in East Central Europe. European Union Politics 3, no. 3: 297326.

Laver, M. and J. Garry. 2000. Estimating Policy Positions from Political Texts. American Journal of Political Science 44, no. 3: 619-634.

Leruth, B. 2014. The New Flemish Alliance's Decision to Join the ECR Group Says More about Belgian Politics than It Does about Their Attitude toward the EU. LSE EUROPP Blog. http://bit.ly/Uxkqlt (accessed 30 December 20I5).

LN. 2009. Proposte e Obiettivi. Programmatic document.

LN. 20I3. Programma Elezioni Politiche 2013. Election manifesto.

LN. 20I4. Elezioni Europee 25 Maggio 2014. Programma Elettorale. EP election manifesto. Malová, D., and P. Učeň. 2012. Slovakia. European Journal Political Research 5I, no. I: 280-7. 
Malová, D., and P. Učeň. 20I3. Slovakia. European Journal of Political Research 52, no. I: 20816.

McDonnell, D. 2014. Despite Renzi's triumph, Euroscepticism is alive and well in Italy. Policy Network Observatory, 2 June. http://www.policynetwork.net/pno_detail.aspx?!D=4669\&title=Despite+Renzi's+triumph\%2c+Euroscep

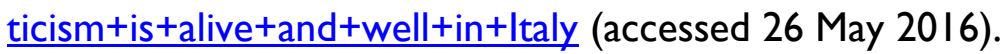

Meijers, M. 2015. Contagious Euroscepticism. The Impact of Eurosceptic Support on Mainstream Party Positions on European integration. Party Politics, doi: $10.1177 /|3540688| 560 \mid 787$.

Moffitt, B. 20I5. How to Perform Crisis: A Model for Understanding the Key Role of Crisis in Contemporary Populism. Government and Opposition 50, no. 2: I89-2I7.

Mudde, C. 2007. Populist Radical Right Parties in Europe. Cambridge: Cambridge University Press.

Pirro, A.L.P. 20I4. Digging into the Breeding Ground: Insights into the Electoral Performance of Populist Radical Right Parties in Central and Eastern Europe. East European Politics 30, no. 2: $246-270$.

Pirro, A.L.P. 2015. The Populist Radical Right in Central and Eastern Europe. Ideology, Impact, and Electoral Performance. London: Routledge.

PVV. 2012. Hún Brussel, Óns Nederland. Election manifesto.

PVV. 20I4. Verkiezingsprogramma Europees Parlement 20I4. EP election manifesto.

Rohrschneider, R., and S. Whitefield. 20I5. Responding to Growing European UnionSkepticism? The Stances of Political Parties toward European Integration in Western and Eastern Europe Following the Financial Crisis. European Union Politics, published online, 26 October, doi: I0.II77//465II65I56/064I. 
Roux, C., and L. Verzichelli. 2010. Italy: Still a Pro-European, but Not a Fully Europeanised Elite?. South European Society and Politics I5, no. I: II-34.

Serricchio, F., M. Tsakatika, and L. Quaglia. 2013. Euroscepticism and the Global Financial Crisis. Journal of Common Market Studies 5I, no. I: 5I-64.

SNS. 2006. Election Programme of the Slovak National Party. Election manifesto.

SNS. 2010. Volebný Program 2010. Election manifesto.

SNS. 20I2. Vernost' Slovensku. Programové Memorandum SNS. Programme memorandum.

SNS. 20I4. Byt' Partnermi, Nie Otrokmi. EP election manifesto.

Swyngedouw, M., K. Abts, and M. Van Craen. 2007. Our Own People First in a Europe of Peoples: The International Policy of the Vlaams Blok. In Europe for the Europeans: The Foreign and Security Policy of the Populist Radical Right, ed. C. Liang, 8I-I0I. Aldershot: Ashgate.

Taggart, P. 1998. A Touchstone of Dissent: Euroscepticism in Contemporary Western European Party Systems. European Journal of Political Research 33, no. 3: 363-88.

Taggart, P. 2000. Populism. Buckingham: Open University Press.

Taggart, P., and A. Szczerbiak. 2008. Introduction: Opposing Europe? The Politics of Euroscepticism in Europe. In Opposing Europe? The Comparative Party Politics of Euroscepticism. Volume I: Case Studies and Country Surveys, ed. A. Szczerbiak and P. Taggart, I-15. Oxford: Oxford University Press.

Taggart, P., and A. Szczerbiak. 2013. Coming in from the Cold? Euroscepticism, Government Participation and Party Positions on Europe. Journal of Common Market Studies 5I, no. I: 17-37.

Van der Meer, T., R. Lubbe, E. Van Elsas, M. Elff, and W. Van der Brug. 20I2. Bounded Volatility in the Dutch Electoral Battlefield: A Panel Study on the Structure of 
Changing Vote Intentions in the Netherlands during 2006-20I0. Acta Politica 47, no. 4: $333-55$.

Van Kessel, S. and Hollander S. 2012. Europe and the Dutch Parliamentary Election, September 2012. EPERN Briefing Paper 7I.

Van Kessel, S. 2015. Populist Parties in Europe: Agents of Discontent? Basingstoke: Palgrave Macmillan.

Vasilopoulou, S. 20II. European Integration and the Radical Right: Three Patterns of Opposition. Government and Opposition 46, no. 2: 223-44.

VB. 2007. Toekomstplan voor Vlaanderen. Election manifesto.

VB. 2009. Dit is ONS Land. Election manifesto.

VB. 20I4. Uw Stok Achter de Deur. Election manifesto.

VVD. 20I4. Europa waar Nodig. EP election manifesto.

Werts, H., P. Scheepers, and M. Lubbers. 2013. Euro-Scepticism and Radical Right-Wing Voting in Europe, 2002-2008: Social Cleavages, Socio-Political Attitudes and Contextual Characteristics Determining Voting for the Radical Right. European Union Politics 14, no. 2: 183-205.

Wilders, G. 2005. Groep Wilders. Onafhankelijkheidsverklaring. Groep Wilders party document. 
Table I. Contextual background of the PRR in five countries

\begin{tabular}{lccccc}
\hline \hline & Belgium & Hungary & Italy & Netherlands & Slovakia \\
& (VB) & (Jobbik) & (LN) & (PVV) & (SNS) \\
\hline $\begin{array}{l}\text { Public opposition to EU } \\
\text { membership }\end{array}$ & Moderate & High & Low & Moderate \\
$\begin{array}{l}\text { EU-pessimist mainstream } \\
\text { competitor }\end{array}$ & No & Yes & Partly & Partly & No \\
$\begin{array}{l}\text { Continued role in opposition } \\
\text { Yes }\end{array}$ & Yes & No & Support & No \\
Recent leadership change & Yes & No & Yes & No & Yes \\
\hline \hline
\end{tabular}


Figure I. Overall orientation of the party leadership towards European integration

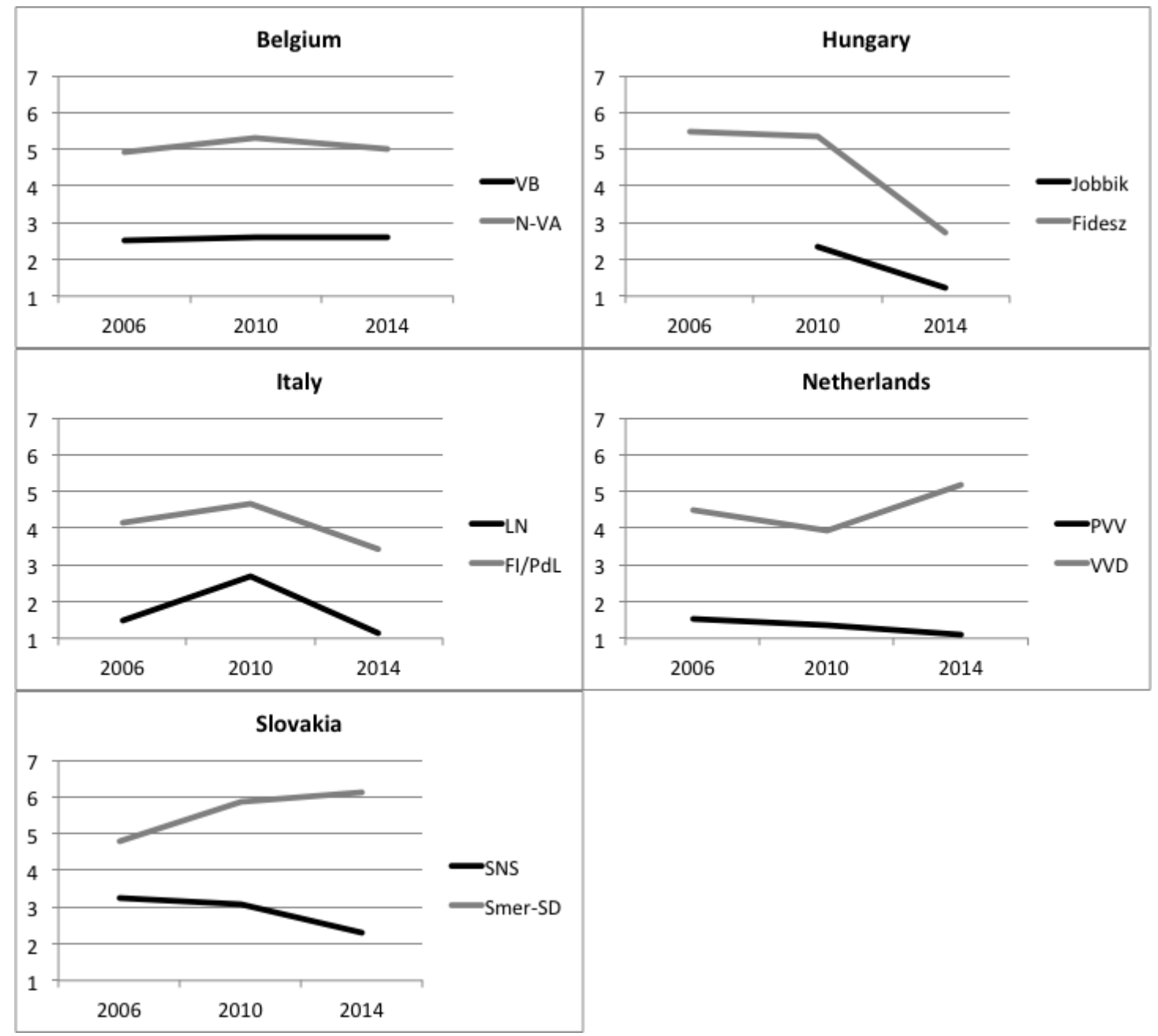

Note: I = Strongly opposed; 4 = Neutral; 7 = Strongly in favour.

Source: 1999-2014 Chapel Hill Expert Survey (CHES) trend file (Bakker et al. 20I5), 'POSITION' variable. 